\title{
PENINGKATAN KEMAMPUAN BERPIKIR KRITIS IPS DALAM PENERAPAN CHARACTER PROJECT CITIZEN (CPC) BERBASIS OUTDOOR STUDY (STUDI PADA SISWA KELAS IV SDN KAMULAN 02 KECAMATAN TALUN KABUPATEN BLITAR)
}

\author{
Nourma Oktaviarini ${ }^{1)}$, Rahmad Setyo Jadmiko ${ }^{2)}$ \\ ${ }^{1}$ STKIP PGRI Tulungagung, ${ }^{2}$ STKIP PGRI Tulungagung \\ E-mail: nourma@stkippgritulungagung.ac.id,jmico1987@gmail.com
}

\begin{abstract}
Abstrak
Character project citizen berbasis outdoor study adalah model dimana siswa belajar di luar ruangan dengan memanfaatkan lingkungan sekitar sebagai sumber belajar, untuk melihat peristiwa langsung di lapangan dengan tujuan untuk mengakrabkan siswa dengan lingkungannya. Tujuan penelitian ini adalah 1) penerapan character project berbasis outdoor study pada mata pelajaran IPS, 2) penerapan character project berbasis outdoor study dapat meningkatkan kemampuan berpikir kritis siswa kelas IV, 3) respon siswa kelas IV SDN terhadap pembelajaran character project citizen berbasis outdoor study. Penelitian ini menggunakan jenis penelitian tindakan kelas (PTK). Hasil penelitian menunjukkan penerapan pembelajaran character project citizen Berbasis Outdoor Study sesuai untuk diterapkan pada pembelajaran IPS denganmateri yang disesuaikan. Hal ini dibuktikan dengan meningkatnya kemampuan berpikir kritis siswa berdasarkan tes dari 3,55 pada siklus I menjadi 4,023 pada siklus II. Kemampuan berpikir kritis berdasarkan pengamatan diperoleh skor 2074 dengan rata-rata skor 69,13 (kategori baik) pada siklus I menjadi 2396 dengan rata-rata skor 79,88 (80) kategori sangat baik. Kesimpulan penelitian ini adalah penerapan Problem Based Learning berbasis Outdoor Study dapat meningkatkan kemampuan berpikir kritis siswa kelas IV pada matapelajaran IPS.
\end{abstract}

PENDAHULUAN

Berpikir kritis merupakan pemikiran yang bersifat selalu ingin tahu terhadap informasi yang ada untuk mencapai suatu pemahaman yang mendalam.Inti kemampuan berpikir kritis menurut Facione (2010:3) meliputi interpretation, analysis, inferensi, evaluation, explanation, dan self-regulation. Pemikir kritis yang ideal memiliki rasa ingin tahu yang besar, teraktual, nalarnya dapat dipercaya, berpikiran terbuka, fleksibel, seimbang dalam mengevaluasi, jujur dalam menghadapi prasangka personal, berhati-hati dalam membuat keputusan, bersedia mempertimbangkan kembali, 
transparan terhadap isu, cerdas dalam mencari informasi yang relevan, beralasan dalam memilih kriteria, fokus dalam penyelidikan, dan gigih dalam mencari temuan.

Hasil observasi langsung peneliti pada siswa kelas IV menunjukkan siswa kurang antusias dan kurang aktif dalam proses pembelajaran, cenderung satu arah. Siswa yang aktif dalam mengikuti proses pembelajaran hanya $27 \%$. Umumnya siswa tidak mampu berpikir kritis sehingga kemampuan memecahkan masalah pada saat diskusi (baik diskusi kelas maupun diskusi kelompok) masih rendah. Hal ini tampak dari pengamatan pada saat diskusi siswa yang aktif hanya 27\% (8 orang siswa). Bila diberikan soal yang memerlukan pemecahan masalah hanya $10 \%$ saja siswa yang dapat menyelesaikan. Data menunjukkan kurang lebih $35 \%$ siswa $40 \%$ siswa mengumpulkan tugas tidak tepat waktu. Rendahnya berpikir kritis ini terlihat dalam perilaku siswa yaitu rasa ingin tahu dalam mencari informasi masih rendah. Hal ini terbukti dari siswa yang hanya menerima informasi dari guru. Sehingga pemahaman siswa terhadap suatu informasi tersebut masih lemah.
Perlu dicarikan solusi dalam mengatasi permasalahan pembelajaran secara tepat, sehingga dapat meningkatkan kemampuan berpikir kritis siswa dalam pembelajaran IPS. Para guru perlu menerapkan berbagai model pembelajaran yang bervariasi agar siswa tertarik dan bersemangat dalam belajar mata pelajaran IPS. Salah satu solusinya yaitu dengan menerapkan pembelajaran Character project citizen berbasis outdoor study sehingga siswa lebih termotivasi dan lebih aktif dalam belajar.

Menurut pendapat Harsono (2011) menyatakan bahwa character project citizen berbasis Outdoor study adalah model dimana guru mengajak siswa belajar menemukan dan memecahkan masalah riil dalam kehidupan bermasyarakat, selain itu mengajak sisiwa belajar di luar ruangan dengan memanfaatkan lingkungan sekitar sebagai sumber belajar, untuk melihat peristiwa langsung di lapangan dengan tujuan untuk mengakrabkan siswa dengan lingkungannya. Konsepkonsep ilmu sosial dan lingkungan sekitar siswa dapat dengan mudah dikuasai siswa melalui pengamatan pada situasi yang konkret. 
Berdasarkan hal-hal tersebut di atas langkah-langkah pembelajaram Character Project Citizen berbasis outdoor study yang dapat dikembangkan oleh guru adalah 1) memberikan orientasi tentang permasalahan kepada siswa, 2) mengirganisasikan siswa untuk belajar, 3) memanfaatkan lingkungan siswa untuk memperoleh pengalaman belajar, 4) membuat aktivitas belajae bekerjasama dengan masyarakat, 5) membimbing penyelidikan individu dan kelompok, 6) mengembangkan dan menyajikan hasil karya, 7) menganalisis dan megevaluasi proses pemecahan masalah dan 8) penilaian. Bekerja dan belajar dalam pembelajaran character project citizen berbasis outdoor studymemberikan nilai lebih, baik bagi siswa itu sendiri maupun bagi lingkungan sekitar. Dengan character project citizen berbasis outdoor studymaka tujuan pembelajaran IPS sebagaimana disebutkan diatas dapat dicapai oleh siswa.

\section{METODE PENELITIAN}

Pendekatan yang digunakan adalah penelitian kualitatif dengan desaian Penelitian Tindakan Kelas (PTK). Dalam penelitian kualitatif, kehadiran peneliti di lapangan mutlak diperlukan karena peneliti bertindak sebagai instrumen kunci yang dalam hal ini adalah sebagai pengamat partisipan. Adapun keterlibatan peneliti selengkapnya dapat dirinci sebagai berikut: peneliti sebagai guru model, perencana kegiatan pembelajaran, pelaksana pembelajaran, pengumpul data, penganalisis, dan pelapor hasil penelitian. Instrumen yang digunakan dalam penelitian ini antara lain observasi, dokumentasi, dan hasil tes.

\section{HASIL PEMBAHASAN}

\section{Siklus I pertemuan 1}

Pada kegiatan pendahuluan Guru membuka pelajaran dengan mengucapkan salam, berdoa bersama dipimpin ketua kelas. Kemudian guru memeriksa kehadiran siswa serta mengkondisikan siswa agar siap belajar. Guru melakukan apresepsi dengan cara melakukan tanya jawab kepada siswa mengenai tugas piket yang diberikan kepada siswa. Apersepsi yang dimulai dengan memberikan pertanyaan kepada siswa dan mengajak siswa mengambil sampah yang ada di dalam kelas.

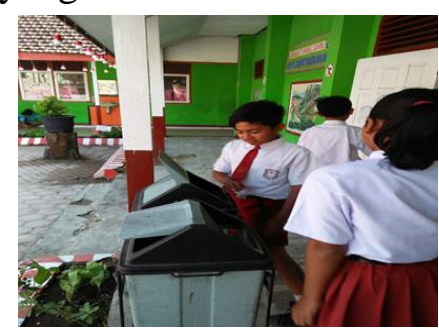


Pada kegiatan eksplorasi guru menunjukkan media bagan mengenai masalah-masalah sosial yang ada di lingkungan sekolah. Pada kegiatan elaborasi guru membentuk siswa menjadi beberapa kelompok, masingmasing kelompok terdiri dari 5 orang siswa Selanjutnya guru memberikan waktu kepada seluruh anggota kelompok untuk mengisi LKS nomor 1 sampai dengan nomor 3. Guru memberitahukan soal selanjutnya bahwa siswa mengadakan wawancara mengenai tanggapan kepala sekolah dan guru tentang sampah di lingkungan sekolah.

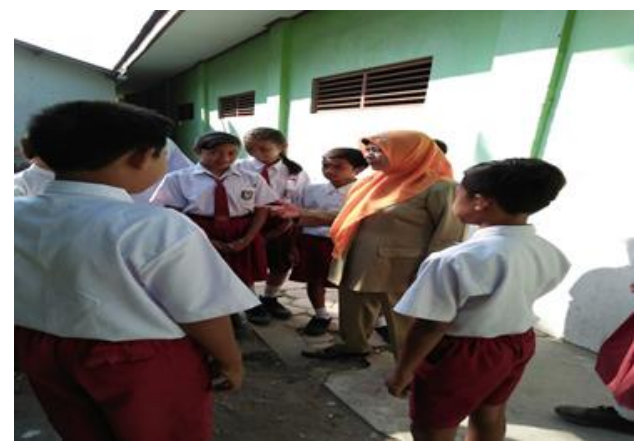

Setelah selesai, siswa bersama dengan guru membahas secara bersamasama LKS yang telah dikerjakan oleh siswa dengan cara membuat lingkaran besar. Salah seorang wakil kelompok mempresentasikan hasil diskusi kelompoknya di tengah-tengah lingkaran.

\section{Siklus II pertemuan 1}

Pada kegiatan pendahuluan guru melakukan apersepsi dengan cara melakukan tanya jawab kepada siswa mengenai media gambar yang ditunjukkan kepada siswa. Pada kegiatan eksplorasi sebelum guru memberikan penjelasan mengenai jenisjenis sampah, guru dan siswa melakukan tanya jawab terkait materi yang sudah dipelajari pada pertemuan sebelumnya. Guru membuat sebuah tabel dipapan tulis, kemudian menyuruh siswa untuk membedakan berbagai macam gambar yang telah ditunjukkan berdasarkan jenis-jenisnya.

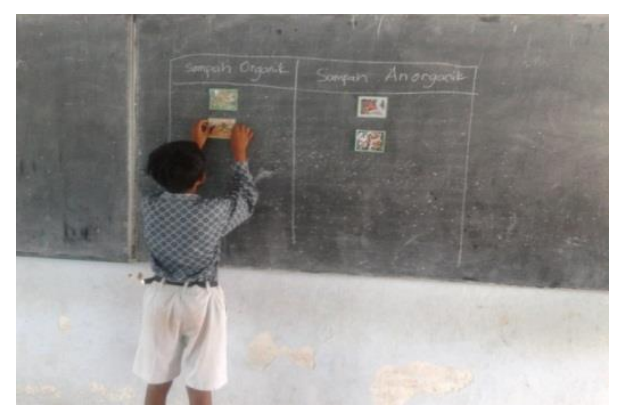

Pada kegiatan elaborasi, guru membagikan Lembar Kerja Siswa (LKS) pada masing-masing kelompok. Guru menjelaskan langkah-langkah dalam mengerjakan LKS. Guru menanyakan mengenai kalimat pada LKS yang belum bisa dimengerti oleh siswa. Guru memberitahukan kepada siswa tentang pengamatan siswa di luar kelas yaitu mengamati sampah yang ada di lingkungan pasar. 


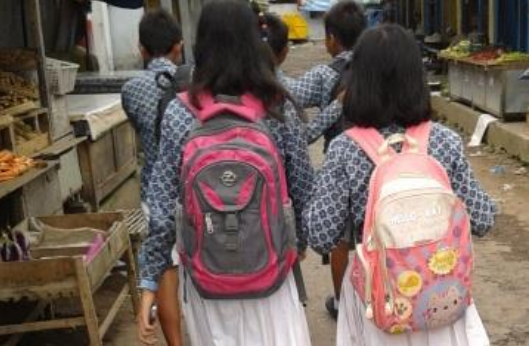

Kegiatan pengamatan siswa di lingkungan pasar ini disambut dengan baik oleh petugas kebersihan di lingkungan pasar Talun yang bernama Bapak Sumadi. Siswa diajak untuk mengamati hasil sampah yang sudah dipilah-pilah oleh para penjual sayur di pasar. Kemudian siswa diajak untuk mengamati lokasi pembuangan akhir di pasar talun.

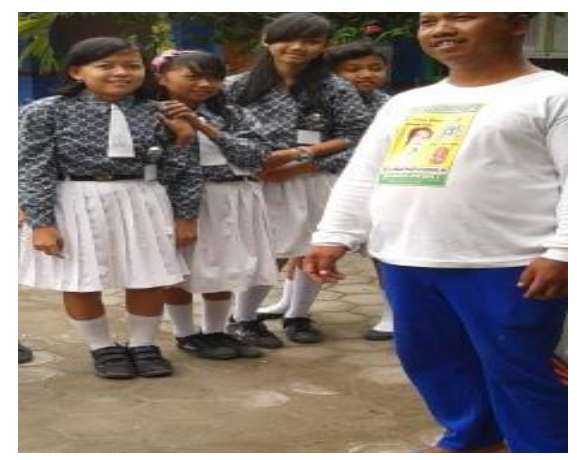

Setelah selesai, siswa bersama dengan guru membahas secara bersamasama LKS yang telah dikerjakan oleh siswa dengan cara membuat lingkaran besar. Salah seorang wakil kelompok mempresentasikan hasil diskusi kelompoknya di tengah-tengah lingkaran. Sedangkan siswa dari kelompok lain memperhatikan dan menanggapi hasil diskusi kelompok yang dipresentasikan di tengah lingkaran.

\section{PEMBAHASAN}

\section{A. Penerapan Character Project} Citizen Berbasis Outdoor Study dengan Mata Pelajaran IPS

Seorang guru tidak cukup hanya berperan untuk memfasilitasi pembelajaran, namun juga harus bisa membantu siswa untuk belajar bagaimana belajar (learn how to learn) agar siswa lebih mudah untuk memahami, menyimpan, dan mengingat kembali konsep-konsep yang dipelajari. Berdasarkan karakteristik materi (dalam hal ini KD 2.4 Mengenal permasalahan sosial di daerahnya) dan solusi pemecahan yang ingin dicapai, maka penerapan model pembelajaran Character project citizen berbasis Outdoor Study merupakan pendekatan yang cocok dalam penelitian ini.

Model pembelajaran Character project citizen memungkinkan siswa untuk belajar konsep dari pemecahan masalah yang meraka lakukan. Dengan kata lain dalam model pembelajaran Character project citizen siswa dapat belajar melalui belajar penemuan (discovery learning). Penemuan terjadi bila siswa terlibat secara aktif dalam 
menggunakan proses mentalnya untuk memperoleh pengalaman, sehingga mereka dapat menemukan beberapa konsep atau prinsip. Proses mental itu meliputi: merumuskan masalah, merumuskan hipotesis, merancang eksperimen, melaksanakan eksperimen, mengumpulkan dan menganalisis data, serta menarik kesimpulan (Fathiyah, 2011:107).

Berdasarkan data hasil pengamatan oleh para observer, keterlaksanaan pembelajaran oleh guru selama siklus I dan II menunjukkan adanya peningkatan tingkat keterlaksanaan. Keterlaksanaan tersebut dapat dilihat pada Tabel1 berikut.

Tabel1. Rata-rata Persentase Keterlaksanaan Pembelajaran oleh Guru pada siklus I dan Siklus II

\begin{tabular}{lll}
\hline \multicolumn{2}{l}{ Rata-rata persentase (\%) } & \multirow{2}{*}{ Peningkatan } \\
\cline { 1 - 2 } Siklus I & Siklus II & \\
\hline 73,35 & 85 & 11,65 \\
\hline
\end{tabular}

Keterlaksanaan pembelajaran oleh guru pada siklus I dan II pun tampak pada

Gambar berikut.

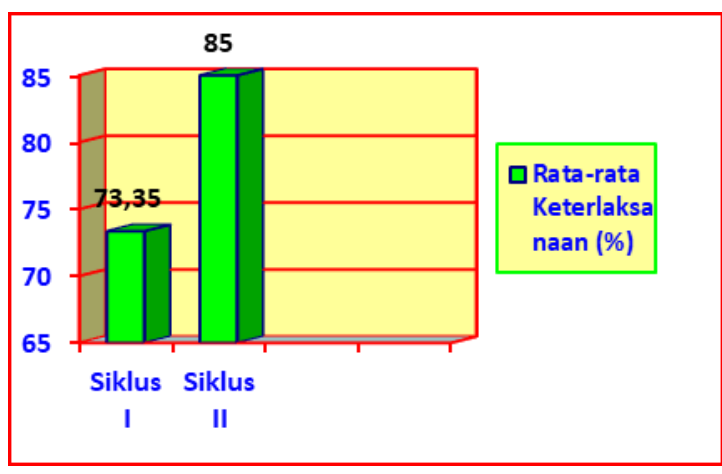

B. Kemampuan Berpikir Kritis Siswa Terhadap Penerapan Character Project Citizen Berbasis Outdoor Study

Belajar memecahkan masalah memerlukan latihan dengan berbagai macam masalah dan membutuhkan pemikiran. Semakin banyak macam masalah yang dipelajari anak didik untuk dipecahkan, maka semakin banyak mereka berpikir (Nur dan Wikandari, 2000 dalm Lutfri, 2003). Menurut Arrends (2008) Character Project Citizen (CPC) merupakan suatu pendekatan pembelajaran dimana siswa mengerjakan pengetahuan mereka sendiri, mengembangkan inkuiri, dan keterampilan berpikir tingkat lebih tinggi, mengembangkan kemandirian dan percaya diri. Menurut Ibrahim (2007:7) (dalam Trianto, 2008:70) penerapan model CPC tidak dirancang untuk membantu guru memberikan informasi sebanyak-banyaknya kepada siswa tetapi membantu siswa mengembangkan kemampuan berpikir, pemecahan masalah, dan keterampilan intelektual, belajar berbagai peran orang dewasa melalui pelibatan mereka dalam pengalaman yang nyata atau simulasi, dan menjadi pebelajar yang otonom dan mandiri. Berpikir kritis dalam 
pembelajaran

merupakan

konseptualisasi kemampuan berpikir secara logis dalam mensintesis referensi untuk memecahkan masalah varu (Glasser, 1985; Skinner,1976 dalam Fathiyah, 2011).

Berdasarkan tes, skor rata-rata kemampuan berpikir kritis pada siklus I dan II mengalami peningkatan. Peningkatan tersebut dapat dilihat pada Tabel 2.

Tabel 2 Rata-rata Skor Kemampuan Berpikir Kritis

\begin{tabular}{lll}
\hline Rata-rata & & Peningkatan \\
\cline { 1 - 2 } Siklus I & Siklus II & \\
\hline 3,55 & 4,023 & 0,473 \\
\hline
\end{tabular}

Rata-rata skor kemampuan berpikir kritis pada setiap tes akhir siklus I dan siklus II tampak pula pada Gambar berikut.

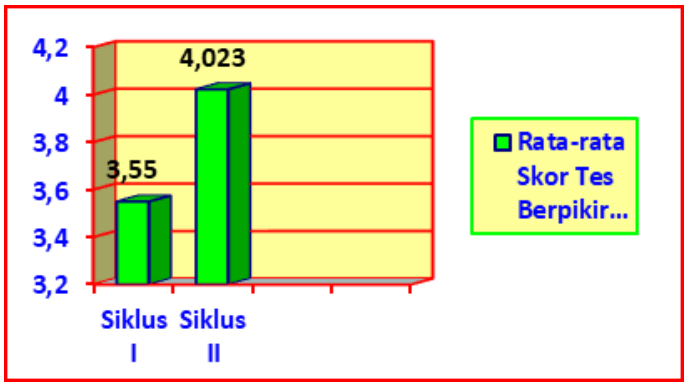

Hasil pengukuran kemampuan berpikir kritis pada siklus I diperoleh skor rata-rata kemampuan berpikir kritis 3,55 (kategori tinggi) sedangkan pada siklus II skor rata-rata kemampuan berpikir kritis mencapai 4,023 (kategori sangat tinggi). Dengan demikian terjadi peningkatan kemampuan berpikir krtis dari siklus I ke siklus II sebanyak 0,473 poin. Peningkatan kemampuan ini dimungkinkan karena selama implementasi CPC, siswa belajar memecahkan masalah.

Berdasarkan hasil pengamatan, skor rata-rata kemampuan berpikir kritis pada siklus I dan II mengalami peningkatan. Peningkatan tersebut dapat dilihat pada Tabel 4.

Tabel 4. Rata-rata Skor Kemampuan Berpikir Kritis

\begin{tabular}{lll}
\hline \multicolumn{2}{l}{ Rata-rata } & \multicolumn{2}{l}{ Peningkatan } \\
\cline { 1 - 2 } Siklus I & Siklus II & \\
\hline 69.13 & 80 & 10.87 \\
\hline
\end{tabular}

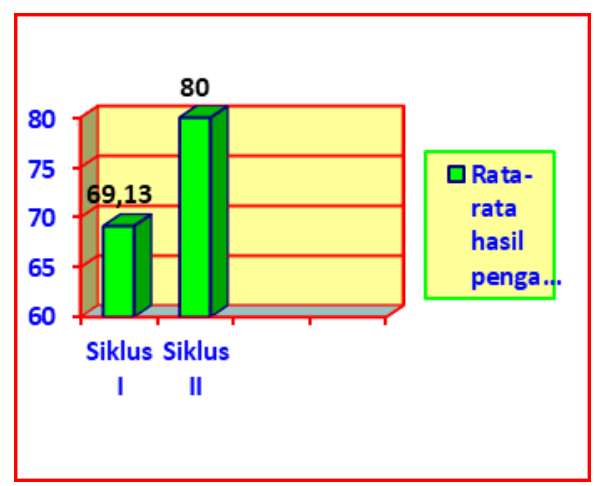

Hasil pengamatan atau observasi pada aktifitas berpikir kritis siswa selama pelaksanaan pembelajaran siklus I diperoleh rata-rata skor 69,13 dengan kategori Baik. Dari pertemuan 1 sebesar 67,06 dan pada pertemuan 2 sebesar 71,2,. Sedangkan hasil pengamatan 
siswa selama pelaksanaan pembelajaran siklus II diperoleh rata-rata skor sebesar 79,88 (80) dengan kategori sangat baik. Dari pertemuan 1 diperoleh skor 77,56 dan skor pertemuan 2 sebesar 82,2.

Dari hasil analisis pengamatan kemampuan berpikir kritis ditemukan bahwa terdapat siswa yang aktif bertanya maupun menjawab tetapi dari hasil tes kemampuan berpikir kritis berbanding terbalik. Hal ini disebabkan siswa dilatih untuk mampu mengaktifkan pikirannya agar memunculkan jawaban, pendapat maupun pertanyaan meskipun pendapat, jawaban dan pertanyaan tersebut tidak benar. Dengan pembimbingan dari guru nantinya diharapkan siswa terbiasa untuk kritis. Sebab menurut Ennis (1993:56) berpikir kritis adalah berpikir reflektif dan masuk akal yang difokuskan untuk memutuskan apa yang harus dipercaya atau dikerjakan.

\section{Respons Siswa terhadap \\ Penerapan Character Project}

\section{Citizen Berbasis Outdoor Study}

Respon siswa terhadap penerapan character project citizen berbasis Outdoor Study diperoleh melalui angket yang diisi oleh subjek penelitian, dalam hal ini adalah siswa kelas IV yang berjumlah 30 siswa. Kisi- kisi dan angket penerapan character project citizen berbasis Outdoor Study dapat dilihat pada Lampiran 31 dan Lampiran 32. Adapun rekapitulasi respon siswa terhadap penerapan character project citizen berbasis Outdoor Study tampak pada Lampiran 33. Secara ringkas data pemunculan setiap deskriptor untuk masing-masing indikator dapat dilihat pada tabel 5 berikut.

Tabel 5 Pemunculan tiap Deskriptor untuk Masing-masing Indikator Respon Siswa terhadap

Penerapan Character Project Citzen Berbasis Outdoor Study

\begin{tabular}{llllll}
\hline Indikator & Deskriptor & Skor & $\begin{array}{l}\text { Rata- } \\
\text { rata }\end{array}$ & $(\%)$ & $\begin{array}{l}\text { Kateg } \\
\text { ori }\end{array}$ \\
\hline $\begin{array}{l}\text { Perhatian } \\
\text { (Attention) }\end{array}$ & $6,9,10$ & 383 & 4,26 & $\begin{array}{l}85,1 \\
\%\end{array}$ & $\begin{array}{l}\text { Sangat } \\
\text { setuju }\end{array}$ \\
$\begin{array}{l}\text { Keyakinan } \\
\text { (Conviden }\end{array}$ & $3,1,4,8$ & 529 & 4,40 & 88,2 & $\begin{array}{l}\text { Sangat } \\
\text { setuju }\end{array}$ \\
ce) & & & & & Sangat \\
Kepuasan & $2,5,7$ & 392 & 4,35 & 87,1 & Setuju \\
(Satisficati & & & & $\%$ & \\
on) & & & & & \\
\hline Rata-rata & & & 4,33 & 86,80 & Sangat \\
& & & & & setuju \\
\hline
\end{tabular}

Sumber: Data dari Lampiran 33

Kategori persentase:

$85 \%-100 \% \quad$ : Sangat setuju

$69 \%-84 \% \quad:$ Setuju

$53 \%-68 \% \quad:$ Ragu-ragu

$37 \%-52 \% \quad$ : Kurang setuju

$20 \%-36 \% \quad$ : Tidak setuju

Tabel 5 di atas menunjukkan bahwa rata-rata respon siswa terhadap setiap deskriptor adalah 4,33 dengan persentase $86,80 \%$ termasuk dalam kategori respon yang positif atau berada pada skala sikap "sangat setuju". Ini 
berarti bahwa pembelajaran dengan menerapkan character project citizen berbasis Outdoor Study menyenangkan bagi siswa.

\section{SIMPULAN DAN SARAN}

\section{Simpulan}

Berdasarkan hasil penelitian, maka dapat disimpulkan penerapan model Character Project Citizen berbasis Outdoor Study pada mata pelajaran IPS Kompetensi Dasar "Mengenal permasalahan sosial di daerahnya" mampu meningkatkan kemampuan berpikir kritis. Hal tersebut terbukti dari sikap keantusiasan mereka dalam memperhatikan pembelajaran yang diberikan peneliti. Siswa lebih aktif berpartisipasi dalam kegiatan pembelajaran, keaktifan siswa misalnya dalam merespon pertanyaan yang diajukan guru serta aktif dalam berdiskusi. Selain itu juga siswa mampu merumuskan masalah, melakukan pengumpulan data berdasarkan pengamatan yang dilakukan, membuat hipotesis, serta siswa sudah tidak mengalami kesulitan dalam membuat kesimpulan terkait dengan hipotesis.

Hasil pengukuran kemampuan berpikir kritis dengan menggunakan instrumen tes dengan bentuk essay pada siklus I diperoleh skor rata-rata kemampuan berpikir kritis 3,55 (kategori tinggi) sedangkan pada siklus II skor rata-rata kemampuan berpikir kritis mencapai 4,023 (kategori sangat tinggi). Dengan demikian terjadi peningkatan kemampuan berpikir krtis dari siklus I ke siklus II sebanyak 0,6473 poin.

Sedangkan hasil pengamatan atau observasi pada aktifitas berpikir kritis siswa selama pelaksanaan pembelajaran siklus I diperoleh rata-rata skor 69,13 dengan kategori Baik. Dari pertemuan 1 sebesar 67,06 dan pada pertemuan 2 sebesar 71,2. Sedangkan hasil pengamatan siswa selama pelaksanaan pembelajaran siklus II diperoleh rata-rata skor sebesar 79,88 (80) dengan kategori sangat baik. Dari pertemuan 1 diperoleh skor 77,56 dan skor pertemuan 2 sebesar 82,2.

\section{Saran}

a. Dalam upaya peningkatan mutu pendidikan di Sekolah Dasar khususnya mata pelajaran IPS, diharapkan guru dalam melaksanakan kegiatan pembelajaran hendaknya menggunakan model, strategi ataupun metode pembelajaran yang sesuai. Memilih dan menerapkan 
model pembelajaran yang menarik dan komunikatif dalam kegiatan pembelajaran sehari-hari di dalam kelas.

b. Berdasarkan hasil penelitian, siswa sangat senang dengan melaksanakan pembelajaran yang bervariasi. Ada kalanya belajar di dalam kelas dan ada kalanya siswa diajak belajar dalam suasana yang berbeda di luar ruangan, agar semangat belajar siswa dapat meningkat.

c. IUntuk penelitian selanjutnya agar pembelajaran dengan menerapkan model Character Project Citizen berbasis Outdoor Study, hendaknya peneliti mempersiapkan terlebih dahulu segala sesuatunya secara matang baik materi, alokasi waktu, kegiatan siswa pada waktu pengamatan di lapangan, penilaian, serta tindak lanjut siswa lebih diperhatikan agar pengkondisian siswa dan kegiatan pembelajaran bisa berjalan secara efektif dan efesien.

d. Untuk kepala sekolah diharapkan mengadakan pembinaan terhadap guru-guru SDN Kamulan 02 Kecamatan Talun Kabupaten Blitar tentang pembelajaran dengan menerapkan model Problem Based Learning berbasis Outdoor Study

e. Disarankan juga untuk mencoba mengembangkan penelitian lanjutan yang membahas tentang peningkatan kemampuan berpikir kritis dan hasil belajar siswa melalui penerapan Character Project Citizen berbasis Outdoor Study.

\section{DAFTAR ACUAN}

Arends, R.I. 2008a. Learning To Teach (Belajar Untuk Mengajar). Edisi ketujuh Buku Satu. Penerjemah Helly Prajitno Soetjipto. Yogyakarta: Pustaka Pelajar.

Arikunto, S \& Jabar, A.S.C. 2009. Evaluasi Program Pendidikan. Pedoman Teoritis Praktis Bagi Mahasiswa dan Praktisi Pendidikan. Edisi Kedua. Jakarta: Bumi Aksara.

Depdiknas. 2006. Standar Isi. Jakarta: Badan Standar Nasional Pendidikan.

Fathiyah, N.R. Implementasi Model Pembelajaran Berdasarkan Masalah Dipadu dengan Strategi Belajar Peta Konsep untuk Meningkatkan Aktivitas, Kemampuan Berpikir Kritis, dan Hasil Belajar Biologi Siswa Kelas VII A SMP Negeri 1 Singosari Kabupaten Malang. Tesis tidak diterbitkan. Malang: 
Program

Pascasarjana

Universitas Negeri Malang.

Harsono. 2011. Penerapan Metode Pembelajaran Out Door Study Objek Lereng Gunung Kelud Guna Meningkatkan Aktivitas, Hasil Belajar, dan Kemampuan Menyusun Karya Tulis Geografi Materi Pemanfaatan Sumberdaya Alam Siswa Kelas XI IPS-2 SMA Negeri 3 Blitar.Tesis tidak diterbitkan. Malang: Program Pascasarjana Universitas Negeri Malang.
Ibrahim, M, dkk. 2003. Pembelajaran Berdasarkan Masalah. Surabaya: University Press.

Nur, M. 2000. Pengajaran Berdasarkan Masalah. Surabaya: UNESA University Press.

Trianto. 2006. Model-Model Pembelajaran Inovatif Berorientasi Konstruktivistik Konsep. Landasan teoritisPraktis dan Implementasinya. Jakarta: Prestasi Pustat. 